\title{
Justification, Pluralism and Pragmatism
}

The Problems and Possibilities of a Peircian Epistemic Justification of Liberalism

\section{Matt Sleat}

\section{(2) OpenEdition}

1 Journals

Electronic version

URL: http://journals.openedition.org/ejpap/539

DOI: $10.4000 /$ ejpap.539

ISSN: 2036-4091

\section{Publisher}

Associazione Pragma

\section{Electronic reference}

Matt Sleat, « Justification, Pluralism and Pragmatism », European Journal of Pragmatism and American Philosophy [Online], V-2 | 2013, Online since 24 December 2013, connection on 01 May 2019. URL http://journals.openedition.org/ejpap/539 ; DOI : 10.4000/ejpap.539

This text was automatically generated on 1 May 2019.

\section{(9) $\Theta \Theta \Theta$}

Author retains copyright and grants the European Journal of Pragmatism and American Philosophy right of first publication with the work simultaneously licensed under a Creative Commons AttributionNonCommercial-NoDerivatives 4.0 International License. 


\title{
Justification, Pluralism and Pragmatism
}

\author{
The Problems and Possibilities of a Peircian Epistemic Justification of \\ Liberalism
}

Matt Sleat

1 The question of how to justify liberal democratic institutions continues to occupy a central role in contemporary political philosophy, undoubtedly buoyed by the actual political relevance that this issue has in many Western societies where staple liberal values and practices such as free speech have become the subject of fierce debate. ${ }^{1}$ Predictably, political philosophers have presented many different forms of justification and have yet to agree which one is the most appropriate. In order to judge whether a justification for liberal institutions is appropriate or not, we must have a criterion or criteria against which to assess it. The aim of this paper is to offer some comments on what these criteria should be in modern liberal societies characterised by a plurality of different and conflicting conceptions of the good, as well as to establish which considerations those justifications must take into account. The argument proceeds largely through critical engagement with Cheryl Misak's recent attempt to offer a Peircian epistemic justification of liberal institutions. ${ }^{2}$ In Truth, Politics, Morality, Misak, a distinguished scholar of the pragmatist philosopher Charles Sanders Peirce, presents an account of how some of Peirce's pragmatist insights can be put to political use, specifically in offering an epistemic justification of liberal institutions. ${ }^{3}$ Drawing attention to the problems that this Peircian justification faces in modern liberal societies will highlight important facets of what a suitable justification for liberal institutions should look like in conditions of pluralism. In particular, examination of Misak's argument enables an analysis of how our conception of the sources of pluralism affects the aims that we think justifications can appropriately have and what the suitable standards of success should be for justifications in conditions of pluralism. The paper concludes by suggesting an alternate application of Peirce's epistemology to the issue of justifying liberal institutions, an application very different to Misak's own and one that has some particularly promising features. 


\section{A Peircian Epistemic Justification}

Misak opens the first chapter of her book by declaring that modern societies are characterised by a plurality of competing conceptions of the good (different and conflicting ideas about what is of worth in life, what ideals we should pursue, what sort of people we should strive to become, etc.) and that this creates, she believes, a specific problem for attempts to justify liberal institutions; for we either appeal to objective, 'universally applicable, categorical standards' to justify those institutions to all individuals regardless of their conception of the good or we adopt a 'hands-off attitude' which says that we cannot adjudicate between conceptions of the good and thus should tolerate them all or treat them all as equally worthy. The problem with the first solution to the problem is that "the proposed standards are simply those thought best by a particular group - usually comfortable white male theorists" while the problem with the second is that it leads to a familiar relativism which renders it difficult to see why toleration rather than oppression is the appropriate response to other conceptions of the good. ${ }^{4}$ Misak cites the Nazi philosopher Carl Schmitt as an example of someone who drew the authoritarian conclusion from this relativistic dilemma. The problem for advocates of the 'hands-off' response to pluralism is that "If there is no objective right or wrong in moral matters, then what prevents one from adopting Schmitt's line rather than the line of tolerance? What can the hands-off liberal say to the Schmittian? If nothing can be said, then it is an indictment of that kind of liberalism." ${ }^{5}$ Misak insists that "A political or moral theory cannot simply ignore such responses. It must have resources to deal with them; it must have something to say about why such responses are mistaken. It must have some way of engaging the illiberal's argument." 6

However, Misak thinks that most recent attempts to justify liberal institutions in conditions of pluralism, such as those offered by Rawls, Rorty and Habermas, have failed to engage the illiberal's argument because they justify liberal institutions with reference to principles that are basically liberal in content which are themselves left unjustified. This is to say that they justify liberal institutions with reference to liberal principles that they simply assume individuals hold. Misak criticises Rawls' notion of the "reasonable," for example, on the basis that he "identifies a reasonable view of the good life with the liberal democratic view" and thus, familiarly, we are told that "despite Rawls' disclaimers, there seems to be a substantive, controversial conception of the good which drives his project" which is decidedly liberal in content. ${ }^{7}$

Yet Misak's problem with these justifications is not merely that they assume liberal principles but that in not justifying those liberal principles Rawls and company are denying themselves any normative resources for justifying liberal institutions to those who are not already committed to those principles, such as Schmitt: "there has been a failure to offer a non-circular or non-question begging justification of the view that we ought to arrange moral and political decision-making around open and free debate with agreement as its aim." ${ }^{8}$ Throughout the book, Schmitt is used as an example of someone for whom such justifications would have lacked any normative force given that they assume rather than justify the very liberal principles that he did not have. As such, these justifications would have given Schmitt no reason to favour tolerant liberal institutions over intolerant authoritarian ones. Misak writes, "Rawls does not provide us with an independent or neutral justification of the liberal or democratic virtues; he just assumes 
those virtues." What we need according to Misak, and what she aims to provide in Truth, Politics, Morality, is a justification for liberal democratic institutions that is not circular or question begging in this way and therefore speaks to the Schmittian.

Misak's argument is that there are resources present in the philosophical work of Peirce that can offer exactly this sort of justification for liberal institutions. The structure of her argument is quite simple: The aim of moral and political inquiry is acquiring true beliefs. The best way to acquire true beliefs is to expose your beliefs to the arguments, reasons and experiences of everyone. This commits us to such liberal values as autonomy, equal moral worth, respect for persons, free speech and toleration. So the justification for liberal institutions is an epistemic one derived from the best methodology for acquiring true beliefs.

of course, each step in this argument is a controversial one and requires defending. That the aim of moral and political inquiry is true belief will be denied by non-cognitivists (or at least insofar as it does aim at truth we will be bitterly disappointed for moral and political propositions are not truth-apt). Against the non-cognitivist Misak says we need to take seriously the phenomenological role that truth plays in moral and political inquiry. So that we ensure that our theory of moral and political inquiry is a theory of moral and political inquiry, and not something else, we need to make sure that our theory preserves the important features of that inquiry, and this requires us, Misak thinks, to take seriously the thought that our moral and political inquiries aim at delivering us true beliefs. ${ }^{10}$ Being a pragmatist Misak dismisses the idea that what we mean by true beliefs are those beliefs that correspond with a believer-independent world. Being a Peircian pragmatist she understands a true belief to be "one upon which inquiry could not improve - a belief which would fit with experience and argument and which would satisfy the aims of inquiry, no matter how much the issue was subject to experiment, evaluation, and debate." ${ }^{11}$

Once we accept this pragmatist conception of truth we can see how the step is made from saying that moral and political inquiry aims at truth to saying that the best way to ensure that our beliefs are true is to make them argument and experience responsive, for a true belief just is one that best fits with experience and argument. Our beliefs change, or should change, insofar as they either fit with or do not fit with reasons and experience. And insofar as we encounter new, better or more decisive reasons and experiences that tell against believing $p$ we must no longer believe $p$ but must believe whatever it is that best fits with these new reasons and experiences.

Out of this conception of truth and belief falls a "methodological requirement" with political consequences: "That methodological principle is that the experience of others must be taken seriously. In the moral and political realm, this requires that everyone be given the chance to contribute to debate. It requires democracy in practice." ${ }^{12}$ Importantly, it means that the experience of all others must be taken seriously for "Those who neglect or denigrate the experiences of others because of their gender, skin colour, or sexual orientation are adopting a very bad means for arriving at true and rational beliefs. They can be criticised as failing to aim at truth properly." ${ }^{13}$ And this methodological principle, Misak believes, can be used to justify many liberal principles, values and institutions such as toleration:

The pragmatist argues that if we are to take seriously the experience of all, we must let ways of life flourish so that they can be articulated and we must let people articulate them for themselves... It is hard to see how anything but a principle of 
tolerance could be the upshot of the methodological principle to take the views of others seriously. ${ }^{14}$

This justification answers to Misak's original problem of wanting to find a neutral justification that has normative force for all, regardless of their conception of the good, in favour of liberal institutions. It is neutral because it appeals to individual's status as a truth-seeker or belief-holder, a status which each individual understands themselves to have no matter what conception of the good they hold. And because each individual understands themselves to be a truth-seeker or belief-holder, this neutrality generates normative force with universal application: "having a belief that is aimed at truth, or at getting things right, is something that every believer is committed to." ${ }^{15}$ Thus we can say to the Schmittian something along the lines of "If you aim at true beliefs then you should allow everyone to speak freely of their reasons and experiences and not oppress groups or individuals as those reasons and experiences may well tell decisively against your beliefs and point you in the direction of truth." So this, let us call it, truth-justification for liberalism derives its normative force by virtue of the fact that it refers to everybody's understanding of themselves, including the Schmittian, as a truth-seeker.

However, because of the way in which Misak defines the truth at which inquiry aims she is able to derive a second associated neutral justification for liberal institutions which relates to the necessary conditions for holding a belief. There are, according to Misak, two constitutive norms of belief. One is that beliefs aim at the truth. ${ }^{16}$ The second is that:

When I believe $p$, I commit myself to saying what could speak for or against $p$ and to giving up $p$ in the face of sustained evidence and argument against it. A belief, in order to be a belief, is such that it is responsive to or answerable to reasons and evidence. That is a very part of what it is to have a belief - it is a constitutive norm of belief. ${ }^{17}$

11 If we hold a belief in a way that is not responsive to reasons and experience, that is to say we would be committed to the belief even in the face of sustained evidence and argument against it, then we can logically be said not to actually believe $p$ at all. As Misak writes:

part of what it is to be a belief, as opposed to some other mental state, such as entertaining an interesting but idle thought, a lie about what one believes, or a dogmatic opinion, is that there must be something that can speak for or against a belief, and that belief must be responsive to what can speak for or against it. ${ }^{18}$ This constitutive norms of belief Misak takes to justify "a kind of radical democracy," requiring us to justify our beliefs to others and to test them against the experience of others which means taking their different perspectives, sensibilities and experiences seriously also. ${ }^{19}$

This justification, let us call it the belief-justification, still takes place against the background of a Peircian account of truth given that Misak still understands the truth at which beliefs aim in Peircian terms. However, it is importantly different from the truthjustification (though Misak often runs them both together) as it derives its normative force in favour of liberal institutions from the Schmittian's understanding of himself as a belief-holder, rather than as a truth-seeker and thus Misak writes that "the requirements of genuine belief show that we must, broadly speaking, be democratic inquirers." ${ }^{20}$

It is important to highlight exactly what sort of justification Misak is employing for there are many different ways in which we might understand the very concept of justification and assessing the cogency of Misak's argument will require us to be clear on this point. Broadly speaking we could say that there are three different forms of justification. The 
first relies upon actual acceptance of X whereby $\mathrm{X}$ is justified only if individuals accept that it is justified. The second form of justification, subjective justification, provides good reasons to believe $\mathrm{X}$ where good reasons are understood to be those that follow from individual's existing beliefs. Insofar as rational individuals do not accept a subjective justification it will either be because it appeals to beliefs that they do not hold or because they are making some mistake about the consequences of their own beliefs. Finally, we might think that reasons can be good reasons to believe $\mathrm{X}$ even if they do not follow from individual's existing beliefs. In this sense they are objective reasons and this form of justification could be called objective justification.

15 Misak's criticism of Rawls' justification is that in appealing to beliefs that not every person holds, it necessarily fails to provide good reasons for supporting liberal institutions to all individuals. Thus she clearly understands Rawls to be offering a subjective justification. In wanting to offer an alternative justification to Rawls' which does not exclude individuals in the same way, Misak could have employed either a different form of subjective justification, one which appeals to beliefs that all individuals hold, or an objective justification. The objective justification might initially look like Misak's best option given that it aims to justify $\mathrm{X}$ by providing good reasons which do not rely upon their fitting with individuals existing beliefs for their normative force. If such objective reasons can be found for supporting liberal institutions then we would have justified them to all individuals regardless of their conception of the good (or of whether they actually accept them or not). However, Misak's Peircian epistemic justification does not aspire to offer objective reasons for supporting liberal institutions. By justifying liberal institutions with reference to individual's understandings of themselves as truthseekers and belief-holders, Misak is offering a subjective justification for liberal institutions, but one which she believes is superior to Rawls' insofar as it provides reasons that all individuals can recognise as good given that it appeals to beliefs that we can assume that all individuals, not just liberals, hold. Once anti-liberals such as Schmitt accept that they are truth-seekers and belief-holders, Misak believes that we can then show them why they have good reasons to support liberal institutions. As Misak writes,

having a belief which is aimed at the truth is something that we can assume of our opponents [in a way that we cannot assume of liberal beliefs or values]. Once that acknowledgement is made (as it is made by the flat-earther, the Nazi, etc.) that one aims at getting the right beliefs, then one is open to a certain sort of criticism. The way is paved for the justification of the democratic principles of inquiry. Once it is acknowledged that we have beliefs, then we can say qua believers, we must abide by certain principles. ${ }^{21}$

In this sense, while Misak's epistemic justification is a subjective one it nevertheless has universalistic aspirations.

\section{The Sources of Pluralism}

It is important to note that Misak does not disagree with Rawls as to which form of justification we should employ but rather as to which beliefs we should appeal to when offering a subjective justification for liberal institutions. Her Peircian epistemic justification is superior, she believes, insofar as it is a justification that appeals to beliefs that we can assume all individuals will hold, regardless of their conception of the good. A question that needs to be addressed is whether this universalistic aspiration to provide justifications for liberal institutions to all individuals, including ardent anti-liberals such 
as Schmitt, is an appropriate aim for justifications in modern liberal societies characterised by a plurality of different and conflicting conceptions of the good?

One way to approach this question is to examine whether, in conditions of pluralism, it is a realistic assumption that all individuals will hold the same belief or beliefs which we can appeal to in order to justify liberal institutions. In order to establish this we need to examine the character of pluralism itself, specifically how different accounts of the sources of pluralism affect the possibility that all individuals, regardless of their conceptions of the good, will hold those same beliefs and from this what the appropriate aims for justifying liberal institutions should be. While Misak locates her disagreement with Rawls at the level of which beliefs we should appeal to when justifying liberal institutions, there are good reasons to think that this difference is only the symptom of a much deeper disagreement regarding the sources of pluralism and that this difference actually precludes Rawls from pursuing the sort of universalistic justification that Misak chastises him for failing to provide. Here would be an instance in which different accounts of the sources of pluralism result in different accounts of the appropriate aims of justification of liberal institutions. Whether Misak is right to criticise Rawls for failing to offer a universalistic justification or not, and indeed whether we should aspire to offer such a justification or not, is going to depend on which account of the sources of pluralism we find the most compelling.

Various contemporary philosophers, Rawls most notably, have identified liberal institutions as playing a central causal role in the creation of pluralism and, as such, that we should expect societies regulated by liberal institutions to be characterised by a plurality of different and conflicting conceptions of the good (it is reasonable). ${ }^{22}$ As Rawls put it:

free institutions tend to generate not simply a variety of doctrines and views, as one might expect from peoples' various interests and their tendency to focus on narrow points of view. Rather, it is the fact that among the views that develop are a diversity of reasonable comprehensive doctrines... They are not simply the upshot of self- and class interests, or of peoples' understandable tendency to view the political world from a limited standpoint. Instead, they are in part the work of free practical reason within the framework of free institutions. ${ }^{23}$

Understanding there to be this sort of causal relationship between liberal institutions and the plurality of different and conflicting conceptions of the good that characterise modern liberal societies must affect our response to pluralism. For example, to think that pluralism is something that we should aim to overcome would require us to take a similar view with regard to liberal institutions themselves, given the central causal role that those institutions play in the creation of pluralism.

With this understanding of the relationship between liberal institutions and pluralism, Rawls rightly drew the conclusion that pluralism is both a permanent fact of modern liberal societies and that, consequently, to regret pluralism would be to regret liberal institutions themselves. As such, pluralism acts as an unavoidable internal constraint on what liberal political philosophy should realistically aspire to achieve. This is particularly evident and relevant when it comes to the issue of justifying liberal institutions in (at least) two ways: First of all, it is no longer a realistic aspiration to try and provide a universalistic justification for liberal institutions that appeals to beliefs which all individuals hold, regardless of their conception of the good. Given the plurality of different and conflicting conceptions of the good, it is not realistic to expect that there will be a belief or set of beliefs which could be used to justify liberal institutions which all 
individuals hold. Thus we must accept that it is highly unlikely that we will be able justify liberal institutions to all individuals regardless of their conceptions of the good.

The second relevant constraint that pluralism places on justifying liberal institutions, and this is related to the first, is that accepting that individuals will hold different and conflicting conceptions of the good, we should also accept that justifications which refer to moral, religious, metaphysical, or epistemological premises will be considered too controversial by many individuals and are therefore inappropriate justifications in conditions of pluralism. As such, the sort of justification that we should seek are those which avoid appealing to controversial moral, religious or philosophical premises over which we can reasonably expect individuals to disagree.

The first constraint is likely to be a controversial one and requires some defending, especially when it might seem that incorporating liberal institutions into our account of the sources of pluralism provides one good reason for thinking that individuals in modern liberal societies will all hold beliefs which could be used to provide a subjective justification for liberal institutions. Because liberal institutions play a central causal role in creating pluralism, we should expect that pluralism to take a largely liberal shape. In which case it is more than likely that individuals will share certain beliefs, common liberal moral or political ones, which could be used to fairly easily provide good reasons for supporting liberal institutions.

Empirically this position is problematic, mainly because many of the problems that face modern liberal societies arise from the cruel irony, which liberal philosophers have long been aware of, that fervently anti-liberal conceptions of the good thrive in societies regulated by liberal institutions, practices and values. These societies offer the conditions for the creation and flourishing of anti-liberal as well as liberal conceptions of the good. The reality of life in modern liberal societies is that pluralism is far from wholly liberal in nature.

More importantly, however, we can provide a philosophical understanding of why liberal institutions do not just create a plurality of different (yet nevertheless still conflicting) liberal conceptions of the good if we think about the premises at work in the argument and what conclusion we can legitimately draw from them. Our initial premise (P1) is that liberal institutions play a central causal role in the creation and sustenance of the plurality of different and conflicting conceptions of the good which characterises modern liberal societies. From this premise, and according to this line of argument, we might draw the conclusion ( $\mathrm{C} 1$ ) that all conceptions of the good which exist within societies regulated by liberal institutions will be of a largely liberal nature and that, consequently, all individuals within those societies could be offered good reasons for endorsing liberalism with reference to liberal beliefs and values that they all share (i.e. a subjective justification). This is, however, too strong a conclusion to draw from our initial premise for while it might be intuitive to think that pluralism will be of a largely liberal nature if liberal institutions play a central causal role in its creation, there is no a priori reason to think that this will be true for all conceptions of the good. Rather, (P1) gives us good reason to think (C2) liberal institutions create societies in which it is highly unlikely (which is to say, the probability is close to though not 0 ) that all citizens are going to hold beliefs which will lead them to support liberalism or enable us to provide a subjective justification why they ought to. This conclusion (C2) accepts that the source of pluralism does have a very important role in determining the nature of the plurality of conceptions of the good, though does not go as far as to say that it plays a totally determining factor 
such that pluralism must be liberal because its source is, to a large degree, liberal institutions themselves.

However, advocates of conclusion (C1) often supplement premise (P1) with a second premise (P2). This is that we should expect conceptions of the good in liberal societies to be broadly liberal in nature because shared liberal institutions exert strong pressure on those individuals who live in the societies that they regulate. The ideas and principles that those institutions express (i.e. liberal ones) are likely to be ideas and principles which individuals come to accept and modify their conceptions of the good appropriately. As Joshua Cohen puts it, "people living within institutions and a political culture shaped by certain ideas and principles are likely to come to understand those ideas and principles and to develop some attachment to them." ${ }^{24}$ Even if we couple (P2) with (P1), however, it would still be invalid to draw conclusion (C1) from it. There does not seem to be any reason to think that this attachment to liberal ideas and principles is something that every individual in liberal societies will develop and indeed it is merely an assumption to think that all individuals regardless of their conception of the good will be sensitive to this institutional pressure to an appropriate degree. Many conceptions, such as religious fundamentalist ones for example, look totally impervious to such pressure. And while we should not doubt that such institutional pressure has and does play an important role in "liberalising" conceptions of the good, this is a process that takes a long time. At any one time there are likely to be many different conceptions of the good at different stages of this modification, where previously anti-liberal conceptions have become liberalised, others have become moderated and others - probably newer conceptions of the good or conceptions that have yet to be adequately exposed to liberal institutions - are still fervently impervious to any justification for them. Thus it would seem unrealistic to think that liberal institutions could be justified to all individuals regardless of their conception of the good at any one time. Given these points, it would be more sensible to draw the weaker conclusion (C2) that it is unrealistic to expect that we will be able to offer good reasons for supporting liberal institutions (according to the subjective model of justification) to all individuals regardless of their conception of the good from premises (P1) and (P2).

Taking this into account, the later Rawlsian project can be best described not as seeking a justification which is neutral between all conceptions of the good, only between all reasonable conceptions of the good. ${ }^{25}$ But it is important to note that the claim being made is not that it is a necessary consequence of pluralism that there will not be some beliefs which are both held in common by all individuals regardless of their conceptions of the good and can be used to provide a subjective justification for liberal institutions. Rather, the claim is that it is highly likely that there will be some conceptions of the good which will not contain beliefs or values which can be used to justify liberal institutions, even if we assume that liberal institutions play a central causal role in the creation of that pluralism. Such liberal homogeneity cannot be simply assumed to occur in relation to people's conceptions of the good because of the role that liberal institutions play in accounting for pluralism. It is therefore appropriate to talk not of pluralism rendering justifying liberal institutions to all people impossible, only unrealistic.

28 In having a different account of the sources of pluralism, Misak is not forced to accept the same conclusions. Misak does not draw this conclusion from the fact of pluralism in large part because she has a different account of the sources of pluralism. The first chapter of Truth, Politics, Morality, which Misak describes elsewhere as 'a catalogue of failed attempts' 
to give a universal justification for liberal institutions,${ }^{26}$ opens by explaining pluralism within modern liberal societies as a result of colonialisation, immigration, war, movement of refugees, redrawing of boundaries, and increased mobility and communication. ${ }^{27}$ What is absent from this account is any sense that liberal institutions themselves might have a causal role in the creation of the plurality of different and conflicting conceptions of the good which characterises modern liberal societies. Misak's account of pluralism makes it sound, we might say, disruptive, in the sense that it takes pluralism to be mostly the result of external forces imposing themselves upon society - as if liberal societies would be homogenous until these forces acted upon it.

Lacking any causal role for liberal institutions themselves, Misak's account of pluralism does not constrain her justificatory aspirations in the same way that Rawls' does. Specifically, Misak can still plausibly aim to offer a justification for liberal institutions which is universalistic in its scope because it appeals to beliefs that we can expect all individuals to hold, regardless of their conception of the good. Of course, if ( $\mathrm{C} 1$ ) had been the appropriate conclusion to draw from the premise that liberal institutions play a central causal role in the creation of pluralism, then Misak might have included liberal institutions in her account of the sources of pluralism with no consequence for her overall argument. If this were the case then it would continue to be an appropriate aim of political philosophy to justify liberal institutions to all citizens regardless of their conception of the good, even if we factor liberal institutions into our account of the sources of pluralism. However, the claim is that once we accept that liberal institutions play a central causal role in the creation of pluralism then we also have to accept the fact that it is highly unlikely that we will be able to offer a subjective justification for liberal institutions to all individuals in modern liberal societies. Including liberal institutions in our account of pluralism therefore alters the realistic scope of justification for those institutions.

The significant consequence of this discussion is that what we understand the sources of pluralism to be effects the scope of application that we think a justification for liberal institutions could realistically have. Crucially, if your account of pluralism posits an intrinsic relationship between a plurality of different and conflicting conceptions of the good and liberal institutions, then given the constraint just discussed, you should be more inclined to suppose that providing a universal justification for those institutions, a justification that all could recognise as offering good reasons regardless of their conception of the good, to be highly unrealistic and therefore not an appropriate aim of political philosophy.

31 Linking this discussion back to Misak's disagreement with Rawls, it is now evident that her criticism of Rawls lies not at the level she identifies, of Rawls offering reasons for supporting liberalism that relate to beliefs that not all individuals will hold and thus is not universal, but at the deeper level of what the aims of justification can realistically be given their different accounts of the sources of pluralism. It is because Misak's account lacks any causal link between liberal institutions and pluralism that she is not constrained by a tension between seeking universal justification for liberal institutions and those institutions themselves. But in not recognising this difference in their accounts of the sources of pluralism and the effects that this has, Misak is led to interpret Rawls' inability to provide universal justifications for liberalism that have normative force to the Schmittian as a failure of those justifications. If the argument just presented is right, however, then this accusation of failure should seem much less compelling. Indeed, if one 
accepts the argument that liberal institutions play a central causal role in the creation of pluralism, and the constraints that this places on the realistic aim of justification, then Rawls' justification should not be seen as the unmitigated disaster that Misak takes it to be.

More broadly than simply helping us locate the actual disagreement between Misak and Rawls, if our account of the pluralism is such that it posits an intrinsic relationship between liberal institutions and pluralism, then we need to stop taking seriously two damaging thoughts that the aspiration for universal justifications encourage (damaging in the sense that the inability to live up to them makes some people consider them failures when in fact they are not thoughts that need to be taken seriously in the first place): First of all, and related to the previous argument, that it is a failure of justifications for liberal institutions if they lack any normative force to the non-liberal such as the Schmittian. In order to properly address this thought we must consider what the appropriate standards of success for justifications should be if not universality. If our account of pluralism accepts that it is unrealistic to expect to be able to justify liberal institutions to everybody, what standards of success are more appropriate? Reconceptualising the standards of success in a way that is not universal though is nevertheless, in some sense, still adequate is one of the first steps that need to be taken in order for us to make any headway on the issue of what sort of justifications are appropriate in conditions of pluralism. If we have not properly engaged in this task then we will continue to disagree on the fundamental question of what the right sort of answer to the issue of justifying liberal institutions would even look like and progress would, therefore, be unlikely. The second and related thought that needs to be addressed is that the failure of our justifications for liberal institutions to have universal normative force gives liberal's good reason to be less committed to those institutions.

\section{Appropriate Standards of Success for Justifications in Conditions of Pluralism}

If we accept that universality is no longer a realistic aspiration for justifications of liberal institutions, then what standards of success should we assess justifications against? If not universality, then what is the appropriate standard of success? One consideration that should be used to guide us in judging the success of a justification is whether or not it broadly matches our considered judgements about which individuals or groups we would expect to be able to relatively unproblematically accept liberal institutions. What would tell against the success of a justification, for example, would be if it provides the Schmittian good reason to accept liberal institutions though excludes individuals with conceptions of the good that we would normally consider, both in theory and in practice, able to endorse those same institutions.

In order to illustrate how such considered judgements could be used to assess the appropriateness of justification it is worth establishing both how Misak's Peircian justification of liberal institutions excludes important groups of individuals which other, non-epistemic, justifications can include and why this renders this justification inappropriate. A large and important group of people for whom Misak's Peircian justification would not provide good reason to accept liberal institutions are those religious believers for whom their religious belief is a matter of faith rather than reason. 
These believers hold their religious beliefs not because they think there are good reasons to do so but because they have made some "leap of faith," they hold their beliefs to be true even though they lack reasons for them (and for shorthand this is what shall now be meant by religious believers). Remember that on Misaks' definition, in order for a belief to be a belief, and not something else like dogmatic opinion, it must both aim at truth (defined in a Peircian way) and be sensitive to the reasons and experiences of others. Where does this leave the beliefs of religious believers?

According to Misak, we cannot actually say that such religious believers are religious believers at all for their beliefs are not responsive to reasons. Misak admits that "At first blush it might seem downright disrespectful to suggest that it [religious belief]... is better described as something other than belief." ${ }^{28}$ But she suggests that we take our cue from Wittgenstein and "see that the view that the religious do not believe, but rather, have faith, is actually more accommodating of the religious point of view." ${ }^{29}$ But accommodating from whose point of view?

Wittgenstein's suggestion, which Misak endorses, is that it would be better "“friendlier" Misak says) for religious "believers" who base the endorsement of their "beliefs" on faith rather than reasons to actually understand themselves as having mental states other than beliefs, faith or dogma for example. Two related points arise: First of all, Misak needs to do some work here to tell us why the category of "faith" is most appropriate to the religious believer and not, as she has previously said with regard to mental states that are not beliefs, mere dogmatic opinion. It is probably right to think that it is "friendlier" to use the term "faith" but it is not clear what distinguishes faith from dogmatic opinion. Indeed it looks like "faith" and "dogmatic opinion" amount to pretty much the same thing given that they are both inferior mental states to beliefs. Nor has she justified why we would necessarily want to be any "friendlier" to the religious believer than the misogynist who takes it as self-evidently true that women are inferior to men. So there is no reason, on Misak's own terms, to think that "faith" rather than "dogmatic opinion" is the term we should apply to the mental states of what we now (mistakenly) call religious believers.

The inferiority issue is not merely a verbal one of religious "believers" wanting to be known as religious believers. Rather, we can see how taking away the category of "belief" as appropriate to religious thoughts that are not reason-responsive actually alters the religious conception of the good. Compare the statement "I believe that Jesus Christ is my saviour!" with the statement "It is my dogmatic opinion that Jesus Christ is my saviour!" Clearly the two statements, understood in Peircian terms, have a very different status. The first indicates an orientation towards the truth that Jesus Christ is my saviour while the second implies a lack of such an orientation and a mere expression of my judgment about Jesus Christ. Though at the initial level this may be an epistemological difference, it is one that has important consequences for individual's relationship to their religious conception of the good. The religious believer who can hold his conception of the good to be grounded in truth is in a significantly different situation from those who hold their beliefs to be matters of opinion unrelated to the truth. And it is entirely plausible to think that this difference may translate into one of the individual's ability to flourish or not. A religious conception of the good that cannot legitimately claim to contain religious beliefs is very different from one that can..$^{30}$

Having removed belief as a description of the mental state of religious believers for whom their beliefs are faith rather than reason based, it is unlikely that many such believers 
will find Misak's Peircian epistemic justification for liberal institutions particularly compelling. The price for accepting this justification is, if you like, far too costly in terms of how they must alter their religious conception of the good. Therefore it is wrong to present the argument as making religious "believers" into something else that allows pragmatism to be more accommodating of their religious conception of the good. Rather, the changes required of the religious conception of the good make those who hold (what would then be) dogmatic religious opinions more accommodating to the pragmatist point of view, more able to accept the Peircian epistemology required to get Misak's justificatory story going. It is reasonable to expect, therefore, that many religious believers would be excluded from accepting liberal institutions by this justification.

Let us assume for the moment that Misak's Peircian epistemic justification is successful in providing good reasons to the Schmittian for why he should support liberal institutions though, for the reasons just stated, unsuccessful in doing the same for religious believers. What should we make of a justification such as this? On the one hand, it would of course be no bad thing if we were able to justify liberal institutions to the Schmittian, indeed to anyone who supports intolerant politics over tolerant ones. In and of itself, there is nothing wrong with this ambitions and indeed the less Nazi's in the world the better. Nevertheless, it is a good sign that something has gone wrong with a justification of liberal institutions if it can provide good reasons for the Nazi to support liberal institutions but not for the religious believer.

The reason why this should be taken as a good sign of the failure of a justification rather than its success is because it sits in considerable tension with some of our considered judgements about which groups of people we would expect a justification to be able to offer good reasons to. Such considered judgements are likely to be vague and rarely work as more than a guiding principle but they do have some important content. One such relevant judgement might be expressed like this: If I am justifying $\mathrm{X}$ to somebody, we would expect to be able to offer good reasons for believing $\mathrm{X}$ which those who already believe X could also accept. Applying this judgement to our current concern, it would seem sensible that a justification for liberal institutions provides good reasons for endorsing those institutions which those groups of people who have been living peacefully in liberal societies for hundreds of years, such as religious believers for example, should be able to accept. Such groups will often hold liberal moral and political beliefs and have lived and participated peacefully in liberal societies, side-by-side with others who hold different and conflicting conceptions of the good. It would be an odd criterion of success for a justification of liberal institutions which did not include providing good reasons to those who already support them for why they are right to do so. A justification should therefore be considered a failure if it cannot provide good reasons to those who have, both in theory and practice, supported liberal institutions, practices and values.

This is not because we should be concerned only with justifying liberal institutions to those who are more like "us," making sure that justifications are acceptable to them first before we turn our attention to those who are less so. Rather, it is a considered judgement about what we expect a justification for liberal institutions to do; that we would expect it, amongst other things but importantly, to provide good reasons to those who have demonstrated their commitment to those institutions why they were right to do so and why they should continue to do so. A justification which did not provide good reasons for supporting liberal institutions to the religious believer, for example, should therefore be 
considered inadequate in a way that is not true if it does not provide good reasons for the Schmittian who is set firmly against liberal institutions, values and practices.

of course, Misak could respond to this by insisting that it is her considered judgement that a justification should indeed be considered a failure if it cannot offer good reasons to the Schmittian, as well as the religious believer, for why he should endorse liberal institutions. Failure to offer good reasons to the Schmittian is just as damaging to a justification for liberal institutions as failure to offer good reasons to the religious believer. Her considered judgement about this matter might be different from the one just suggested. However, if the argument of the previous section is right, then this judgement might be incompatible with the realistic prospects of justifying liberal institutions in conditions of pluralism. If, in modern liberal societies characterised by pluralism, we cannot realistically expect to be able to offer good reasons to all individuals regardless of their conception of the good, then a consequence of this should be that we do not instantly class a justification a failure if it cannot justify liberal institutions to all people. In which case, our considered judgements might come into play in providing some guidance into which groups of people we consider it more or less likely to be able to offer good reasons in favour of liberal institutions to. This can then be used to determine which groups we do and do not have to offer good reasons to in order for a justification to be deemed successful. Most groups of religious believers, and other groups who have supported liberal institutions for centuries, would seem to be located at one end of this spectrum and the Schmittian much nearer the other.

Yet this argument runs the risk of looking somewhat conservative, in the sense that we might think that all a justification has to do in order to be deemed successful is to offer good reasons for supporting liberal institutions to those who already do so. No effort need me made, therefore, in trying to justify them to those individuals whose support is wavering or somewhat precarious and especially not to those who are vehemently antiliberal such as the Schmittian. The best way to present the argument is to insist that it is a necessary though not a sufficient condition of a successful justification for liberal institutions that it does provide good reasons to groups who support them. This means that a justification for liberal institutions should always seek to provide good reasons to those who do not support them but that success in this endeavour does not, by itself, determine the overall success of the justification.

As a quick aside, this suggests that epistemic justifications, not just of a Peircian variety, may be particularly unwieldy in delivering a justification which might map onto our considered judgements in this way. This is not just because they take positions on philosophical issues such as truth, belief and knowledge, philosophical issues that are controversial and thus we can reasonably expect individuals to disagree over. Rather, there is no reason to think that epistemic justifications are going to be able to even crudely mirror our considerations as to which groups an adequate justification of liberal institutions would include (evident in the fact that Misak's Peircian epistemic justification may possibly be acceptable to the Schmittian though likely unacceptable to religious believers). If they do, this is more likely to be a result of luck than intention.

\section{Doubting Liberal Institutions}

The argument so far has been that there is no obvious reason to think that a justification for liberal institutions is inadequate if it is unable to provide good reasons (according to a 
subjective model of justification) to the Schmittian for why he should support them. At certain points in Truth, Politics, Morality, Misak presents a different though related claim for why we might consider a justification which could not provide good reasons to the Schmittian inadequate - a claim related more to the effect that this failure should have on our commitment to liberal institutions. "We want," Misak writes, "to be able to say that the neo-Nazi for instance, has got things wrong or is immoral and we want to be able to explain to ourselves, in a convincing manner, why we are so right to oppose him." ${ }^{31}$ Towards the end of the book she puts the point more forcefully:

If my reasons [for advocating tolerance] are parochial and latch on to nothing which is common to all, then they might as well have as little persuasive power with me as they do with others. It is hard to resist the thought that I have no reason for advocating tolerance other than it is what strikes me as right. ${ }^{32}$

According to this argument, being unable to justify liberal institutions to the Schmittian is not just a failure of those justifications but a failure that should disrupt our own commitment to those institutions. Is Misak right to think our commitment to liberal institutions should be put into question if we cannot provide good reasons for endorsing them to all individuals regardless of their conception of the good?

This thought is linked to the belief, examined above, that any justification for liberal institutions is inadequate if it cannot provide good reasons to the Schmittian. But we have seen that failure to offer good reasons for endorsing liberal institutions to the Schmittian is not an obvious failure of those justifications in conditions of pluralism. If this is no longer a necessary criterion of success then it would be inappropriate for those already committed to liberal institutions to begin to doubt that there are good reasons to continue supporting them.

We might think, however, that the very existence of non-liberals who seem impervious to our justifications for liberal institutions, and endorse intolerant authoritarian institutions instead, provides good reason for us to question the rightness of those institutions? This is very doubtful indeed. Difference, even radical differences of moral and political values such as that embodied by the liberal and the Schmittian, is not in itself a reason to be dissatisfied with liberal institutions in exactly the same way that knowing that some people think the world is flat or that a sexual relationship with children is healthy gives me reason to doubt that the world is round or paedophilia is a moral wrong. So the mere existence and persistence of the Schmittian who rejects liberal institutions, practices and values does not give me reason to question those institutions.

This conclusion is also strengthened if we accept that a plurality of different and conflicting conceptions of the good is one of the central characteristics of modern liberal societies and, even more so, if we think that there is an intrinsic relationship between liberal institutions and pluralism of the good. If we think the latter, then we should think it highly likely that there will always be individuals that hold conceptions of the good that are not going to incline them to endorsing liberalism (in Rawls' terminology, they are not reasonable). Again, if disagreement and difference is understood as intrinsically linked to liberal institutions then they can hardly be considered reasons to be dissatisfied with those institutions, unless we want to see disagreement and difference as inherently undesirable - in which case such a person is very unlikely to be liberal in the first place. Thus, nothing should follow in terms of our commitment to liberal institutions from our inability to convince the Schmittian nor the fact that our disagreement with the Schmittian is intractable. 

thought which Misak does not utilise. Further than this, these resources might also give us good reason to think that Rawls' moral rather than Misak's epistemic justification for liberal institutions is closer to the spirit of Peirce's own epistemology. We can use Peircian epistemology to defend Rawls against Misak's claim that moral justifications that are themselves not justified are arbitrary and therefore inadequate. In other words, there is a possible different application of Peirce's philosophy to the issue of justifying liberal institutions which not only has features that make it look more promising than Misak's own - which shall merely be hinted at - but gives us a defence of moral justifications for those institutions therefore further undermining the argument of Truth, Politics, Morality. of central aspects of Peirce's epistemology that Misak retains is the thought that "a belief requires a justification when, and only when, it has been thrown into doubt by actual inquiry." ${ }^{33}$ The demand that we justify our beliefs only arises when we have good reason to doubt that they are true. As such, we do not have to be able to justify all of our beliefs nor do we have to be able to justify all of our beliefs all of the time. Even though this idea is central to Peirce's philosophy, and even though Misak seems to endorse it, it nevertheless plays a minor role in the argument of Truth, Politics, Morality. Emphasising this Peircian thought about only needing to justify our beliefs when we have good reason to doubt them allows us to understand Misak's initial disagreement with Rawls as misplaced. In short, there are good Peircian reasons for Misak to endorse rather than disagree with Rawls' moral justifications of liberal institutions.

mem that Misak's locates her disagreement with Rawls at the level of his justification assuming certain liberal beliefs, values or virtues rather than actually justifying them. This is a version of the well rehearsed claim that the concept of "reasonable" is morally loaded in the liberal's favour and as such the notion that reasonable citizens support liberal institutions amounts to nothing more than the tautology that liberals support liberalism. ${ }^{34}$ Rawls is quite clear that part of what it means to be reasonable is to regulate your actions according to the criterion of reciprocity when it comes to the use of the exercise of political power: "our exercise of political power is proper only when we sincerely believe that the reasons we offer for our political action may reasonably be accepted by other citizens as a justification of those actions." ${ }^{35}$ And from the criterion of reciprocity Rawls derives the liberal principle of legitimacy whereby it is legitimate to use political power only when it is exercised in accordance with a constitution the essentials of which all citizens may reasonably be expected to endorse. ${ }^{36}$ Therefore, to try and use state power to promote your conception of the good, for example, would violate the liberal principle of legitimacy for you would be using state power in a way that we could not reasonably expect others to accept.

This commitment to reciprocity Rawls, and other liberal philosophers such as Larmore and Macedo, see as following from the moral belief that humans are free and equal and should be treated as such or from the belief that all humans deserve equal respect. ${ }^{37}$ Because I believe that you and I are both free and equal human beings, I want to ensure that the institutions and laws that regulate our society are as justifiable to you as they are to me. It is this moral belief that lies at the heart of the concept of being reasonable and therefore Misak amongst others are right to say that the concept of reasonable has nonneutral and moral content. But this is hardly a discovery nor does it amount to Rawls relying on a particular conception of the good as Misak argues. There is a big and important difference between justifying liberal institutions with reference to a particular 
conception of the good and with reference to a moral belief that is central to many conceptions of the good, not all comprehensively liberal.

Nevertheless, thinking about this justification of liberalism within a Peircian framework, according to Peirce we only have reason to justify a belief if we have good reason to doubt it. Applied to what we are discussing here, this would translate into the thought that I only have reason to justify my belief that liberal institutions are the best or right way to regulate modern societies if I have reason to doubt that all humans are free and equal and are to be treated as such, the moral belief central to the concept of being reasonable. According to this line of thinking, we should only begin to doubt our commitment to liberal institutions if we have good reason to doubt our justificatory moral belief that all humans are free and equal or deserving of equal respect.

This application of Peircian epistemology to the issue of justifying liberal institutions gives rise to some promising possibilities worth briefly listing: Maybe the most promising benefit is that Peirce's epistemology gives us a way of responding to those argumentative moves which insist that justifying liberalism with reference to moral beliefs is illegitimate if those moral beliefs themselves are not justified. This argument is a particularly damaging one for many contemporary liberal theorists who take seriously the fact of pluralism and the constraints that it puts on what sort of justifications are appropriate as they then have to make one of two moves. They can either try to justify those moral beliefs, but it is unlikely that they will be able to do so in a way that avoids controversial philosophical and religious issues, or they can admit that, in some sense, those moral beliefs cannot be justified but that we should still be committed to them given that they are arbitrarily ours (something similar to the position of Rorty). What Peirce's epistemology allows us to do is resist the thought that we need to justify those moral beliefs but to also still insist that those beliefs are true (unless, of course, we are given good reason to doubt them). In this sense, the critical sting is taken out of the charge that liberal philosophers such as Rawls merely assume rather than justify the liberal moral beliefs that are central to their justifications for liberal institutions. And as this criticism is usually followed by accusations of circularity or that it results in relativism, Peirce would seem to give us reasons to resist them as well. It would be a major advantage of any moral justification of liberal institutions if it were able to resist these criticisms of arbitrariness, circularity, or relativism and therefore this looks like a particularly promising facet of a Peircian account.

Second, Peirce's epistemology can actually be used to explain why there is no need for Peircian or indeed any variety of epistemic justification for liberal institutions. For reasons suggested above, there might be good grounds for thinking that epistemic justifications, justifications that refer to what it is to hold a belief or to properly seek truth, are inappropriate in conditions of pluralism and therefore any other argumentative tool that can be used to stave off such justifications would be welcome. Finally, this Peircian thought can help us deflect the idea that failure to justify liberal institutions to all should give us good reason to question the rightness of liberal institutions. On a Peircian defence of Rawls, such failure does not give us good reason to doubt that others are free and equal and should be treated as such and therefore neither does it give us reason to doubt liberal institutions. Again, though there are other explanations for why we should not accept this argument, it is unlikely, as with most things, that the one argument is ever likely to be sufficient. 


\section{Conclusion} justify liberal institutions in conditions of pluralism. Much time has been spent establishing that Misak's Peircian epistemic justification is an inappropriate way of justifying liberal institutions in modern liberal societies characterised by a plurality of different and conflicting conceptions of the good. However, and more importantly, engagement with Misak's account has allowed us to make some more general remarks about the enterprise of justifying liberal institutions in conditions of pluralism, specifically how different understandings of the sources of pluralism relate to what we should consider the relevant concerns and aims of justifications to be, the appropriate standard of success for justifications of liberal institutions in conditions of pluralism, and how such standards should affect our commitment to those institutions. Some of the promising possibilities that might derive from a different approach to applying Peircian epistemology to the issue of justifying liberal institutions have also been sketched. However, though this application of Peirce's thought might have some very promising features, the final determination of whether it can come good on its promise or not is whether it is an appropriate form of justification in conditions of pluralism, taking into account some of the broader conclusions that have been drawn here.

\section{BIBLIOGRAPHY}

COHEN J., (1994), “A More Democratic Liberalism,” Michigan Law Review 92, 1503-46.

LARMORE C., (1990), “The Moral Basis of Political Liberalism,” Charles Larmore, 'Political Liberalism', Political Theory 18, August 1990, 339-60.

LARMORE C., (1999), “The Moral Basis of Political Liberalism,” The Journal of Philosophy 96, 599-625.

MACEDO S., (1990), “Politics of Justification," Political Theory 18, May, 280-304.

MISAK C., (2000), Truth, Politics, Morality - Pragmatism and Deliberation, London, Routledge.

MISAK C., (2004), “Making Disagreement Matter: Pragmatism and Deliberative Democracy,” Journal of Speculative Philosophy 18, 9-22.

MENDUS S., (2002), Impartiality in Moral and Political Philosophy, Oxford, Oxford University Press, 18-25.

Mouffe C., (1994), “Political Liberalism. Neutrality and the Political," Ratio Juris 7, 314-24.

RAWLS J., (1996), Political Liberalism, Chichester, Columbia University Press, 1996, 36-37.

TALISSE R., (2005), Democracy after Liberalism - Pragmatism and Deliberative Politics, London, Routledge, 2005, 103-21.

European Journal of Pragmatism and American Philosophy, V-2 | 2013 
Westbrook R., (2005), Democratic Hope - Pragmatism and the Politics of Truth, London, Cornell University Press, 44-51.

\section{NOTES}

1. The recent worldwide protests and debate that followed the publication of a cartoon in a Danish newspaper of the Prophet Muhammad is a striking example of how fundamental liberal values are being contested.

2. Misak (2000). Misak actually talks mostly about using Peircian epistemology to justify deliberative democracy. I will, however, be discussing her argument in terms of a justification for liberal institutions. I do not think that anything hangs on this difference given that many of the same things are being justified (e.g. freedom of speech, toleration, moral equality of all, etc.) and that Misak herself probably does not understand there to be any significant difference between them given that she criticises the position of philosophers such as Rorty whom it is hard to say is a deliberative democrat. Also, I think my arguments against Misak's justification remain if we understand her to be justifying deliberative democracy instead of liberal institutions.

3. By common consensus Misak's book represents the most thorough exposition and defence of how Peircian pragmatism can be used to justify liberal institutions and is endorsed by other pragmatists as a promising account of such a justification. See, for example, Westbrook (2005: 44-51), and Talisse (2005: 103-121). Westbrook goes as far as to say that Misak's book is the strongest argument "yet offered for claiming a democratic political valence for pragmatism," Westbrook (2005: 51).

4. Misak (2000: 9-2).

5. Misak (ibid.: 11).

6. Misak (ibid.: 11).

7. Misak (2000: 24).

8. Misak (ibid.: 5).

9. Misak (ibid.: 25).

10. Misak (2000: 3).

11. Misak (ibid.: 1). As Misak herself states, this is a variation of a Peircian understanding of truth which has some significant advantages over Peirce's own. See also (ibid.: 49-50).

12. Misak (ibid:: 6).

13. Misak (ibid.: 104). Emphasis added.

14. Misak (ibid.: 115).

15. Misak (2000: 106).

16. See (ibid.: 51) and Misak (2004: 14).

17. Misak (2004: 12).

18. Misak (2000: 74).

19. Misak (ibid.: 94).

20. Misak (ibid., 106).

21. Misak (2000: 46). Emphasis in the original.

22. See also, for example, Larmore (1999).

23. Rawls (1996: 36-37).

24. Cohen (1994).

25. Though it is probably even more accurate, though cumbersome, to say that he sought a justification that was neutral between all reasonable conceptions of the good for a conception of justice that was neutral in aim between all reasonable conceptions of the good. Rawls did not understand himself as providing a justification that was neutral because it appealed to intuitive 
ideas implicit in the public political culture of modern liberal democracies. However, this just means that it cannot be neutral between all conceptions of the good and it is more illuminating of the structure of Rawls' later work, I think, to see it as trying to offer a justification that is neutral though only between all reasonable conceptions of the good.

26. Misak (2004: 11).

27. Misak (2000: 9).

28. Misak (2000: 75).

29. Misak (ibid.: 75).

30. The argument of this paragraph parallels the argument that Susan Mendus has persuasively made against the appropriateness of Brian Barry's scepticism in conditions of pluralism. See Mendus (2002).

31. Misak (2000: 16). Emphasis added.

32. Misak (ibid.: 103-104).

33. Misak (2000: 52).

34. Probably the most forceful expression of this concern can be found in Mouffe (1994).

35. Rawls (1996: xlvi).

36. See (ibid.: xlvi, 137 and 217).

37. See for example Larmore (1990), Macedo (1990).

\section{ABSTRACTS}

This article explores the problems and possibilities of offering a compelling Peircian epistemic justification of liberal institutions, primarily via critical engagement with the work of Cheryl Misak, and uses this to make some wider points about the criteria for a successful justification of liberalism in conditions of pluralism. Though the article argues that Misak's argument fails to take seriously enough the problem that pluralism poses for the justification of liberal politics in modern democratic societies, and that in this sense a version of political liberalism is superior, it nevertheless ends by tentatively suggesting an alternative account of a Peircian epistemological justification that has some potentially promising and attractive features.

\section{AUTHOR}

\section{MATT SLEAT}

University of Sheffield

m.sleat[at]sheffield.ac.uk 